\title{
Soil moisture influence on the interannual variation in temperature sensitivity of soil organic carbon mineralization in the Loess Plateau
}

\author{
Y. J Zhang ${ }^{1,2}$, S. L Guo ${ }^{1,3,4}$, M. Zhao ${ }^{4}$, L. L. Du ${ }^{1}$, R. J. Li ${ }^{1}$, J. S. Jiang ${ }^{3}$, R. Wang ${ }^{4}$, and N. N. Li ${ }^{1}$ \\ ${ }^{1}$ State Key Laboratory of Soil Erosion and Dry-land Farming on the Loess Plateau, Institute of Soil and Water Conservation, \\ Northwest A\&F University, Yangling 712100, China \\ ${ }^{2}$ Geography and Environmental Engineering Department, Baoji University of Arts and Sciences, Baoji 721013, China \\ ${ }^{3}$ Institute of Soil and Water Conservation, Chinese Academy of Sciences and Ministry of Water Resource, Yangling 712100, \\ China \\ ${ }^{4}$ College of Resources and Environment, Northwest A\&F University, Yangling 712100, China
}

Correspondence to: S. L. Guo (slguo@ms.iswc.ac.cn)

Received: 29 October 2014 - Published in Biogeosciences Discuss.: 22 January 2015

Revised: 11 May 2015 - Accepted: 15 May 2015 - Published: 12 June 2015

\begin{abstract}
Temperature sensitivity of soil organic carbon (SOC) mineralization (i.e., $Q_{10}$ ) determines how strong the feedback from global warming may be on the atmospheric $\mathrm{CO}_{2}$ concentration; thus, understanding the factors influencing the interannual variation in $Q_{10}$ is important for accurately estimating local soil carbon cycle. In situ SOC mineralization rate was measured using an automated $\mathrm{CO}_{2}$ flux system (Li-8100) in long-term bare fallow soil in the Loess Plateau $\left(35^{\circ} 12^{\prime} \mathrm{N}, 107^{\circ} 40^{\prime} \mathrm{E}\right)$ in Changwu, Shaanxi, China from 2008 to 2013 . The results showed that the annual cumulative SOC mineralization ranged from 226 to $298 \mathrm{~g} \mathrm{C} \mathrm{m}^{-2} \mathrm{yr}^{-1}$, with a mean of $253 \mathrm{~g} \mathrm{C} \mathrm{m}^{-2} \mathrm{yr}^{-1}$ and a coefficient of variation $(\mathrm{CV})$ of $13 \%$, annual $Q_{10}$ ranged from 1.48 to 1.94 , with a mean of 1.70 and a CV of $10 \%$, and annual soil moisture content ranged from 38.6 to $50.7 \%$ soil water-filled pore space (WFPS), with a mean of $43.8 \%$ WFPS and a CV of $11 \%$, which were mainly affected by the frequency and distribution of precipitation. Annual $Q_{10}$ showed a quadratic correlation with annual mean soil moisture content. In conclusion, understanding of the relationships between interannual variation in $Q_{10}$, soil moisture, and precipitation are important to accurately estimate the local carbon cycle, especially under the changing climate.
\end{abstract}

\section{Introduction}

Temperature sensitivity of soil organic carbon (SOC) mineralization (hereafter referred to as $Q_{10}$ ) is of critical importance because it determines how strong the feedback from global warming may be on atmospheric $\mathrm{CO}_{2}$ concentration (Agren and Wetterstedt, 2007). However, this is an issue of considerable debate (Davidson et al., 2006; Kirschbaum, 2006), and the variations in $Q_{10}$ are the main source of controversy on this feedback intensity (Larionova et al., 2007; Karhu et al., 2010; Conant et al., 2011; Sakurai et al., 2012). Therefore, understanding the factors influencing $Q_{10}$ is important to accurately estimate $\mathrm{C}$ cycle and the feedback from the expected warmer climate.

Previous studies have shown that $Q_{10}$ variations are closely related to soil temperature (Kirschbaum, 2006; Von Lutzow and Kogel-Knabner, 2009), substrate availability (Ågren and Wetterstedt, 2007; Gershenson et al., 2009), substrate quality (Von Lutzow and Kogel-Knabner, 2009; Sakurai et al., 2012), and the size and composition of a microbial population (Djukic et al., 2010; Karhu et al., 2010). Soil moisture is the most significant limiting factor for underground physiological processes in dry and semi-dry ecosystems (Balogh et al., 2011; Cable et al., 2011; Wang et al., 2014). Soil water availability may indirectly affect $Q_{10}$ by influencing the diffusion of substrates because the diffusion of extracellular enzymes produced by microorganisms and 
available substrates must occur in the liquid phase (Davidson et al., 1998; Illeris et al., 2004), but the response of $Q_{10}$ to soil water availability is extremely complex and controversial (Davidson et al., 2000; Davidson et al., 2006; McCulley et al., 2007). For example, Gulledge and Schimel (2000) found that $Q_{10}$ was larger in wet years than in drought years, whereas the opposite result was found by Dörr and Münnich (1987). However, many other studies that mainly focused on the short-term or seasonal variation in $Q_{10}$ (Davidson et al., 2006) have shown that $Q_{10}$ was not affected by soil moisture (Fang and Moncrieff, 2001; Reichstein et al., 2002; Jassal et al., 2008). Additionally, soil water availability experienced marked seasonal and interannual fluctuations in these ecosystems due to uneven rainfall distribution caused by the abnormal increase of atmospheric $\mathrm{CO}_{2}$ concentrations (Solomon et al., 2007). The uneven rainfall distribution inevitably influenced soil moisture availability (Coronato and Bertiller, 1996; Qiu et al., 2001; Cho and Choi, 2014). Xiao et al. (2014) showed that the interannual changes in soil moisture storage in the Loess Plateau were decided by the difference in soil moisture storage between October and April because precipitation from April to October of 2004 to 2010 accounted for at least $86 \%$ of annual rainfall. However, to our knowledge, there have been few studies investigating the relationship between interannual variation in $Q_{10}$ and soil moisture under natural conditions.

The Loess Plateau is located in northwest China, covering an area of $640000 \mathrm{~km}^{2}$. It has a continental monsoonal climate and shows dramatic interannual fluctuations in precipitation, with the highest precipitation of $1262 \mathrm{~mm}$ and the lowest precipitation of only $80 \mathrm{~mm}$, and a mean value of 150 $750 \mathrm{~mm}$ (Lin and Wang, 2007). The precipitation in the loess regions also shows dramatic seasonal variation, and approximately $60-80 \%$ of the annual precipitation falls during the three summer months from July to September (Guo et al., 2012). Several recent studies have attempted to determine the dominant factors responsible for the variation of soil respiration in vegetation ecosystems (Lafond et al., 2011; Shi et al., 2011; Jurasinski et al., 2012). However, there have been no studies on the interannual variation in $Q_{10}$, nor the factors responsible for these changes. This highlights the need to accurately evaluate the response of SOC mineralization to increasing temperature under warmer climate scenarios in eroded or degraded regions because air temperature has been increasing over the past few decades (Fan and Wang, 2011; Wang et al., 2012). Thus, the objectives of the present study are to (1) quantify the interannual variation in $Q_{10}$; (2) determine the effect of soil moisture on this interannual variation for the period 2008-2013 in the Loess Plateau, China.

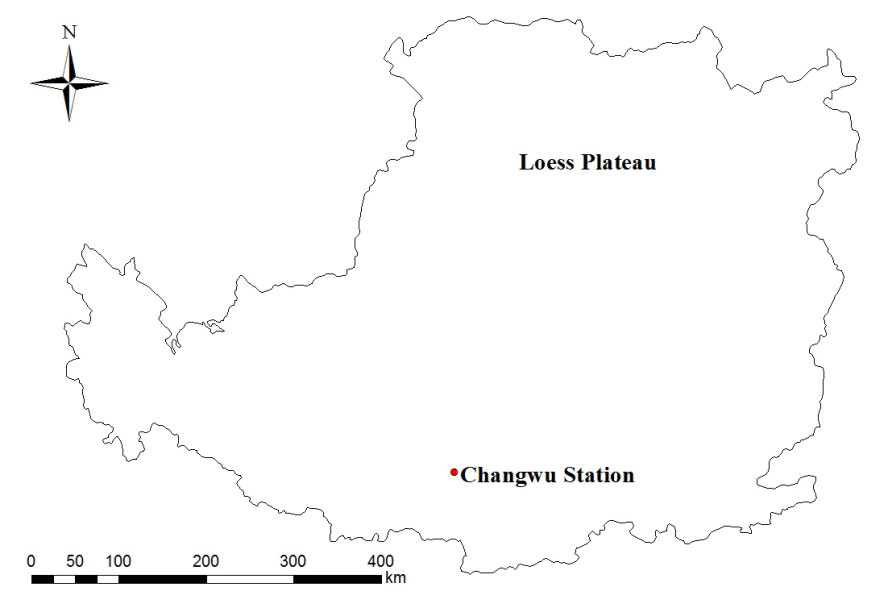

Figure 1. Location of the State Key Agro-Ecological Experimental Station (Changwu Station).

\section{Materials and methods}

\subsection{Site description}

This study was a part of a long-term field experiment that began in 1984 in the State Key Agro-Ecological Experimental Station in the Loess Plateau in Changwu, Shaanxi, China $\left(35^{\circ} 12^{\prime} \mathrm{N}, 107^{\circ} 40^{\prime} \mathrm{E} ; 1200 \mathrm{~m}\right.$ above sea level; a.s.l.) (Fig. 1). This region had a continental monsoon climate with a mean annual precipitation of $560 \mathrm{~mm}$ for the period 1984-2013, over $60 \%$ of which occurred from July to September. During this 30-year period, the annual mean air temperature was $9.4^{\circ} \mathrm{C}$ and the monthly mean temperature between July and September was $19.4^{\circ} \mathrm{C}$. The study site is also characterized by a $\geq 10^{\circ} \mathrm{C}$ accumulated temperature of $3029^{\circ} \mathrm{C}$, an annual sunshine duration of $2230 \mathrm{~h}$, an annual total radiation of $484 \mathrm{~kJ} \mathrm{~cm}^{-2}$, and a frost-free period of 171 days.

The site was located in a typical rain-fed cropping region of the Loess Plateau highland in northwest China. The soil was classified as a loam (Cumulic Haplustoll, USDA Soil Taxonomy System) developed from loess deposits. Soils collected at the study site in 1984 at a depth of $0-20 \mathrm{~cm}$ contained $10.5 \% \mathrm{CaCO}_{3}, 6.5 \mathrm{~g}$ organic $\mathrm{C} \mathrm{kg}^{-1}, 0.80 \mathrm{~g}$ total $\mathrm{N} \mathrm{kg}^{-1}$, and $200 \mathrm{mg} \mathrm{NH}_{4} \mathrm{OAc}-$ extractable $\mathrm{K} \mathrm{kg}^{-1}, 3.0 \mathrm{~g} \mathrm{~kg}^{-1}$ available phosphorus, and had a $\mathrm{pH}$ of 8.4 (with a $1: 1$ ratio of soil: $\mathrm{H}_{2} \mathrm{O}$ ), a water-holding capacity of $0.29 \mathrm{~cm}^{3} \mathrm{~cm}^{-3}(v / v)$, a wilting point of $11 \%$, a soil bulk density of $1.3 \mathrm{~g} \mathrm{~cm}^{-3}$, soil porosity of $51 \%$, and a clay content of $24 \%$.

\subsection{Experimental design and management}

A total of 36 treatments were used in the long-term field experiment, including bare fallow, continuous monoculture, and rotations of wheat, legume, and maize with varying fertilizer rates. The plot used in the present study is taken from a bare plot in a state of fallow since June 1984 after the har- 
vesting of winter wheat (Triticum aestivum L. "Chang Wu 131 series"), and live weeds were removed in a timely manner. Therefore, there was no vegetation or inputs of aboveground and belowground litter, and thus SOC mineralization rates in the bare fallow soil did not include root respiration and litter mineralization and decomposition. In this paper, three bare fallow plots were used to investigate the mechanism of underground SOC mineralization rates. All plots of $10.3 \mathrm{~m} \times 6.5 \mathrm{~m}\left(66.95 \mathrm{~m}^{2}\right)$ were randomly arranged in three blocks. The plots were separated by $0.5 \mathrm{~m}$ spaces, whereas the blocks were separated by $1 \mathrm{~m}$ strips.

\subsection{Measurements of SOC mineralization rate and soil microclimate}

SOC mineralization rate was measured using an automated closed soil $\mathrm{CO}_{2}$ flux system with a portable chamber $(20 \mathrm{~cm}$ in diameter, Li-8100, Lincoln, NE, USA). Approximately 1 day before the first measurement, a polyvinyl chloride (PVC) collar ( $20 \mathrm{~cm}$ in diameter and $12 \mathrm{~cm}$ in height) was inserted to a depth of $2 \mathrm{~cm}$ into each plot, and left in place throughout the experimental period from 2008 to 2013. Five PVC collars were installed in our plots for investigating the spatial variation of SOC mineralization rate in summer (11 July 2008) and winter (18 November 2008), respectively. Although previous studies have demonstrated a significant spatial variation of soil respiration, especially in the sites with complex terrain (causing the redistribution of SOC) and different vegetation types (Epron et al., 2006; Luan et al., 2012), the spatial variation of SOC mineralization rate in our sites is small with a variation coefficient of only 4 and $5 \%$ in summer and winter, respectively (Table 1). The results implied that the temporal fluctuation during the measurement has little effect on the spatial variation of SOC mineralization rate. This could be due to the fact that there have been no vegetation or inputs of (aboveground and belowground) litter in our plots since 1984 (absolute fallow), and the soil was derived aeolian deposit loess and flat terrain. Due to the small areas of our plots $\left(66.95 \mathrm{~m}^{2}\right)$ and time constraints ( $5 \mathrm{~min}$ for measuring SOC mineralization rate in a given PVC collar), only one PVC collar was used in each plot for measuring SOC mineralization rate and only twice were measurements taken for studying the spatial variation of SOC mineralization rate in our plots. All visible living organisms were removed before the measurement. If necessary, one or more additional measurements were taken until the variations between two consecutive measurements were less than $15 \%$. The final instantaneous soil respiration for a given collar was the average of the two measurements with a $90 \mathrm{~s}$ enclosure period and $30 \mathrm{~s}$ delay between them. Field measurements were performed between 09:00 and 11:00 CST. from March 2008 to November 2013, except in December, January, and February because of cold weather. A total of 17, 25, 26, 22, 26, and 17 SOC mineralization measurements were made in 2008 2013.
Soil temperatures and water contents at a $5 \mathrm{~cm}$ depth were measured at a distance of $10 \mathrm{~cm}$ from the chamber collar at the same time as the SOC mineralization rates using a Li-Cor thermocouple probe and a Theta Probe ML2X with a HH2 water content meter (Delta-T Devices, Cambridge, England), respectively. Daily mean soil temperature and moisture data were provided by the State Key Agro-Ecological Experimental Station, both of which were measured at $5 \mathrm{~cm}$ below the surface using a Hydra soil moisture sensor (Hydra Data Reader and Hydra Probe II Soil Moisture Sensor (SDI12/RS485); precision: moisture, $\pm 0.5 \%$ vol; temperature, $\pm 0.6^{\circ} \mathrm{C}$; Stevens Water Monitoring Systems Inc., Australia). Soil water-filled pore space (WFPS) was calculated as follows: WFPS $(\%)=100 \times$ [volumetric water content $/(2.65-$ soil bulk density)/2.65], with 2.65 being the particle density of the soil $\left(\mathrm{g} \mathrm{cm}^{-3}\right)$.

\subsection{Data analysis}

An exponential (or $Q_{10}$ ) function was used to simulate the relationship between SOC mineralization rate and soil temperature (Xu and Qi, 2001):

$F=\beta_{0} e^{\beta_{1} T}$,

$Q_{10}=e^{10 \beta_{1}}$,

where $F\left(\mu \mathrm{mol} \mathrm{m} \mathrm{m}^{-2} \mathrm{~s}^{-1}\right)$ is the SOC mineralization rate, $T$ $\left({ }^{\circ} \mathrm{C}\right)$ is the soil temperature at a depth of $5 \mathrm{~cm}$, and $\beta_{0}$ and $\beta_{1}$ are the fitted parameters.

A quadratic polynomial function was used to simulate the relationship between SOC mineralization rate and soil moisture content (Tang et al., 2005):

$F=\beta_{3} \theta^{2}+\beta_{2} \theta+\beta_{4}$,

where $\theta$ is the soil moisture at a depth of $0-5 \mathrm{~cm}$, and $\beta_{2}, \beta_{3}$, and $\beta_{4}$ are the fitted parameters.

The interactions of soil temperature with moisture content can more accurately simulate soil respiration than either soil temperature or moisture alone (Tang et al., 2005). Our data indicated that SOC mineralization rate increased with increasing soil moisture content to a maximum at approximately $46 \%$ WFPS, and then decreased with further increase of soil moisture content. After comparing different functions and resulting residual plots, a bivariate model was used to simulate the effect of soil moisture content and temperature on SOC mineralization rate:

$F=\beta_{0} e^{\beta_{1} T \theta+\beta_{2} T \theta^{2}}$.

The annual cumulative SOC mineralization rate was estimated by linear interpolating between measurement dates to obtain the mean daily SOC mineralization rate for each plot, and then summing the mean daily SOC mineralization rate for a given year.

The relationships between $Q_{10}$ and meteorological factors were investigated using SAS software (version 8.0; SAS 
Table 1. SOC mineralization rate $\left(\mu \mathrm{mol} \mathrm{m} \mathrm{m}^{-2} \mathrm{~s}^{-1}\right)$ in summer (11 July 2008) and winter (18 November 2008). Data are represented as mean \pm SD of five collars.

\begin{tabular}{lcccccc}
\hline \multirow{2}{*}{ Dates } & \multicolumn{5}{c}{ SOC mineralization rate } \\
\cline { 2 - 7 } & Collar 1 & Collar 2 & Collar 3 & Collar 4 & Collar 5 & Mean value \\
\hline Summer & $1.55 \pm 0.11$ & $1.60 \pm 0.20$ & $1.58 \pm 0.21$ & $1.49 \pm 0.07$ & $1.65 \pm 0.18$ & $1.57 \pm 0.06$ \\
Winter & $0.29 \pm 0.01$ & $0.30 \pm 0.02$ & $0.31 \pm 0.01$ & $0.32 \pm 0.02$ & $0.33 \pm 0.02$ & $0.31 \pm 0.02$ \\
\hline
\end{tabular}

Note: SOC mineralization rate was measured on 11 July 2008 and 18 November 2008 (representing summer and winter) using five PVC collars installed in our plots.

Table 2. Cumulative SOC mineralization rate $\left(\mathrm{g} \mathrm{C} \mathrm{m}^{-2} \mathrm{yr}^{-1}\right)$, annual precipitation amount $(\mathrm{mm})$, annual precipitation days, and air temperature $\left({ }^{\circ} \mathrm{C}\right)$ from 2009 to 2013. Data are represented as mean \pm SD.

\begin{tabular}{lrrrr}
\hline Years & $\begin{array}{r}\text { Cumulative SOC } \\
\text { mineralization rate }\end{array}$ & $\begin{array}{r}\text { Precipitation } \\
\text { amount }\end{array}$ & $\begin{array}{r}\text { Precipitation } \\
\text { days }\end{array}$ & $\begin{array}{r}\text { Air } \\
\text { temperature }\end{array}$ \\
\hline 2008 & $293 \pm 10$ & 520 & 105 & 9.76 \\
2009 & $298 \pm 9$ & 481 & 99 & 10.26 \\
2010 & $238 \pm 50$ & 588 & 101 & 10.39 \\
2011 & $234 \pm 48$ & 644 & 100 & 9.43 \\
2012 & $226 \pm 19$ & 481 & 98 & 9.43 \\
2013 & $240 \pm 30$ & 523 & 71 & 11.08 \\
Mean & $253 \pm 32$ & $540 \pm 64$ & $96 \pm 12$ & $10.1 \pm 0.6$ \\
\hline
\end{tabular}

Institute, Cary, NC). All other statistical analyses were performed with ANOVA at $P=0.05$.

\section{Results}

\subsection{Interannual variation in $Q_{10}$}

The temporal variation in SOC mineralization rate was correlated with that of soil temperature in all 6 years (Fig. 2b and c), and it increased exponentially with soil temperature $(P<0.01)$. The mean annual SOC mineralization rate ranged from 0.83 (2012) to $1.22 \mu \mathrm{mol} \mathrm{m}{ }^{-2} \mathrm{~s}^{-1}$ (2008), with a mean of $0.99 \mu \mathrm{mol} \mathrm{m}^{-2} \mathrm{~s}^{-1}$ and a coefficient of variation (CV) of $17 \%$; the annual cumulative SOC mineralization ranged from 226 (2012) to $298 \mathrm{~g} \mathrm{C} \mathrm{m}^{-2} \mathrm{yr}^{-1}$ (2009), with a mean of $253 \mathrm{~g} \mathrm{C} \mathrm{m}^{-2} \mathrm{yr}^{-1}$ and a CV of $13 \%$ (Table 2), and the annual $Q_{10}$ in our sites was 1.65 in 2008, 1.94 in 2009, 1.72 in 2010, 1.48 in 2011, 1.86 in 2012, and 1.55 in 2013, respectively, with a mean $Q_{10}$ of 1.72 and a CV of $10 \%$ (Table 3).

\subsection{Interannual variation in soil microclimate}

Annual precipitation showed a significant annual variation (Fig. 1 and Table 2; $P<0.05$ ). Rainfall ranged from 481 (2009 and 2012) to $644 \mathrm{~mm}$ (2011), with a 6-year mean of $540 \pm 64 \mathrm{~mm}$ and a CV of $12 \%$. Annual rainfall days ranged from 71 (2013) to 105 days (2008), with a 6-year mean of $96 \pm 12$ days and a CV of $13 \%$. Interannual variation in air temperature was not significant (Fig. 1 and Table 2;
$P>0.05$ ). It ranged from 9.43 (2011 and 2012) to $11.08^{\circ} \mathrm{C}$ (2013), with a 6-year mean of $10.1 \pm 0.6^{\circ} \mathrm{C}$ and a $\mathrm{CV}$ of only $6 \%$.

Soil temperature and soil moisture at a depth of $0-5 \mathrm{~cm}$ showed significant temporal variations over the 6-year observation period (Fig. 2b). The seasonal mean soil moisture content was 49.2\% WFPS in the wet season (July to September in each year) and $38.6 \%$ WFPS in the dry season (other months). The mean annual soil moisture content ranged from $38.6 \%$ WFPS (2013) to $50.7 \%$ WFPS (2011), with a mean of $43.8 \%$ WFPS and a CV of $11 \%$. The seasonal mean soil temperature was $14.50^{\circ} \mathrm{C}$ in the dry season and $20.39^{\circ} \mathrm{C}$ in the wet season. The mean annual soil temperature ranged from $14.90^{\circ} \mathrm{C}$ (2011) to $18.42^{\circ} \mathrm{C}$ (2009), with a mean of $17.05^{\circ} \mathrm{C}$ and a $\mathrm{CV}$ of only $7 \%$.

\subsection{Effect of soil moisture on the interannual variation of $Q_{10}$}

Annual $Q_{10}$ showed a negative quadratic correlation with annual mean soil moisture (Fig. 3b). Additionally, the seasonal SOC mineralization rate increased exponentially with soil temperature, and showed a negative quadratic correlation with soil moisture content (Table 3). The response surface of SOC mineralization rate to soil temperature and moisture including both seasonal and interannual scales clearly described how soil microclimate influenced the SOC mineralization rate (Fig. 4).

\section{Discussion}

\subsection{Soil moisture influenced the interannual variation in $Q_{10}$}

The range of annual $Q_{10}(1.48-1.94$, with a CV of $10 \%)$ in our sites for the period 2008-2013 was within the limits reported for annual $Q_{10}(1.20-4.89)$ at the global scale (Boone et al., 1998; Zhou et al., 2007; Gaumont-Guay et al., 2008; Zhu and Cheng, 2011; Zimmermann et al., 2012). However, the mean annual $Q_{10}$ in our sites (1.70) was lower than the global mean (2.47) (Boone et al., 1998; Zhou et al., 2007; Gaumont-Guay et al., 2008; Zhu and Cheng, 2011; Zimmermann et al., 2012), probably due to low SOC contents, small 
Table 3. Relationships between SOC mineralization rate and soil temperature $(F-T)$ or soil moisture $(F-\theta)$ for each year from 2008 to 2013.

\begin{tabular}{llrrrllrr}
\hline Years & \multicolumn{9}{c}{$F-T$} & & & \\
& \cline { 2 - 10 } & Functions & $R^{2}$ & $P$ & $Q_{10}$ & Functions & $R^{2}$ & $P$ \\
\hline 2008 & $F=0.49 e^{0.0499 T}$ & 0.56 & $<0.01$ & 1.65 & $F=-0.0008 \theta^{2}+0.10 \theta-1.52$ & 0.53 & $<0.01$ \\
2009 & $F=0.34 e^{0.0661 T}$ & 0.63 & $<0.01$ & 1.94 & $F=-0.0001 \theta^{2}-0.02 \theta+2.63$ & 0.61 & $<0.01$ \\
2010 & $F=0.35 e^{0.0544 T}$ & 0.47 & $<0.01$ & 1.72 & $F=0.0002 \theta^{2}-0.04 \theta+2.15$ & 0.86 & $<0.01$ \\
2011 & $F=0.45 e^{0.0395 T}$ & 0.47 & $<0.01$ & 1.48 & $F=-0.0008 \theta^{2}+0.06 \theta+0.06$ & 0.46 & $<0.01$ \\
2012 & $F=0.27 e^{0.0623 T}$ & 0.67 & $<0.01$ & 1.86 & $F=-0.0019 \theta^{2}+0.14 \theta-1.71$ & 0.35 & $<0.05$ \\
2013 & $F=0.52 e^{0.0441 T}$ & 0.32 & $<0.01$ & 1.55 & $F=-0.001 \theta^{2}+0.08 \theta-0.60$ & 0.36 & $<0.05$ \\
\hline
\end{tabular}
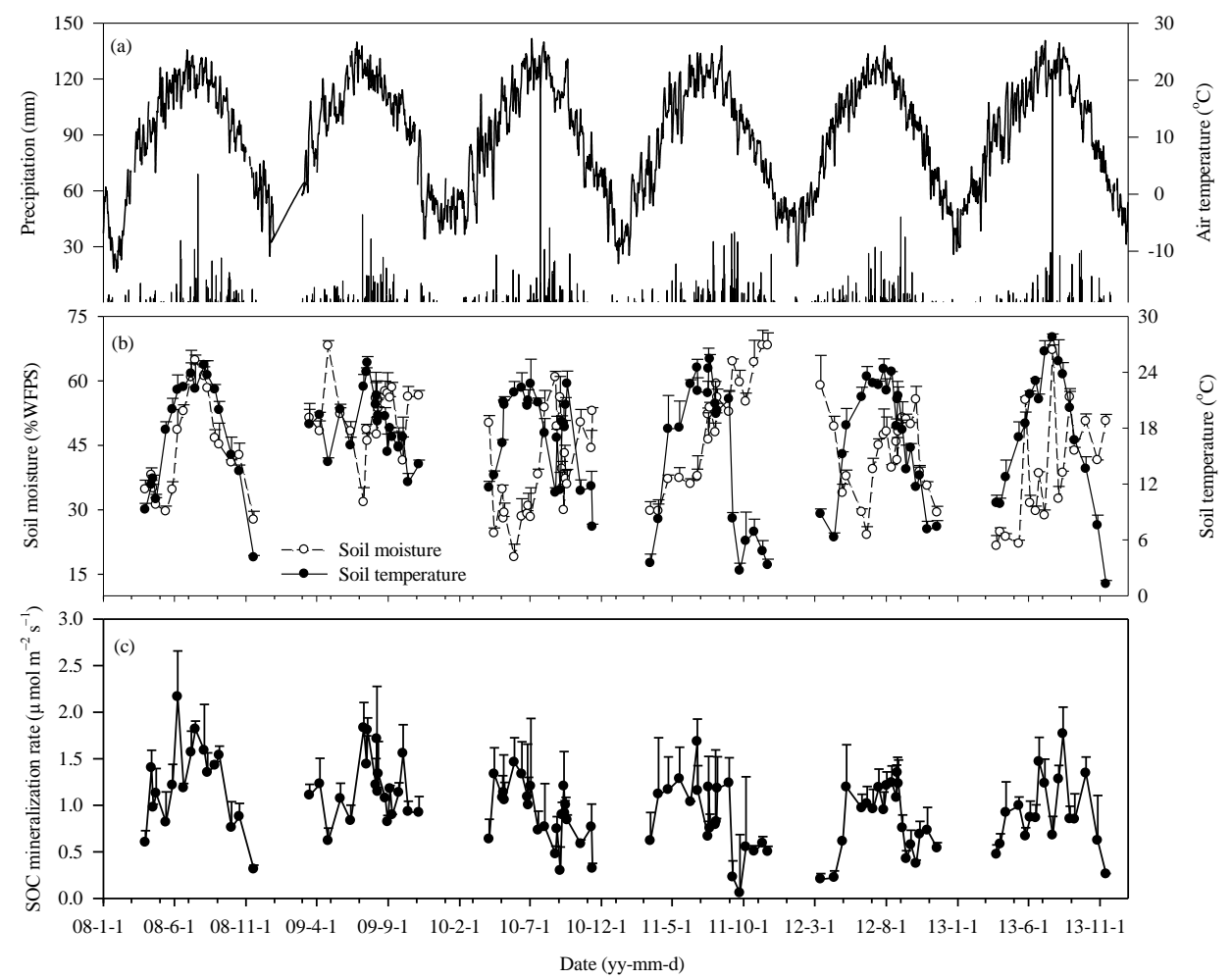

Figure 2. Temporal variations of (a) precipitation and air temperature, (b) soil moisture and soil temperature, and (c) SOC mineralization rate from 2008 to 2013 .

microbial communities, dry soil conditions in semi-arid regions (Conant et al., 2004; Gershenson et al., 2009; Cable et al., 2011), and different methods used for separating the SOC mineralization rate (Boone et al., 1998; Zhu and Cheng, 2011; Zimmermann et al., 2012).

Annual $Q_{10}$ was negatively linearly correlated with annual mean precipitation, but this correlation did not reach statistical significance $(P>0.05)$; whereas it was significantly related to soil moisture content (Fig. 3). This was in agreement with previous studies (Suseela et al., 2012; Poll et al., 2013). However, $Q_{10}$ was found to be negatively correlated with mean annual precipitation $(P<0.01)$ in different forest ecosystems in China, which could be due to the relatively abundant rainfall in the forest ecosystems (700$1956 \mathrm{~mm}$ ) (Peng et al., 2009). Soil moisture was the major limiting factor for underground biological processes, especially in water-limited regions (Reth et al., 2005; Balogh et al., 2011; Wang et al., 2014). Although precipitation was the only source of water for soil moisture underneath longterm bare soil, there was no significant relationship between annual mean soil moisture and annual precipitation amount $(P>0.05)$ (Fig. 5a), but rainfall frequency and distribution were closely related to annual mean soil moisture content (Fig. 5b). Similar results have also been found in other studies (Coronato and Bertiller, 1996; Qiu et al., 2001; Cho and Choi, 2014). The annual precipitation during the 6-year 

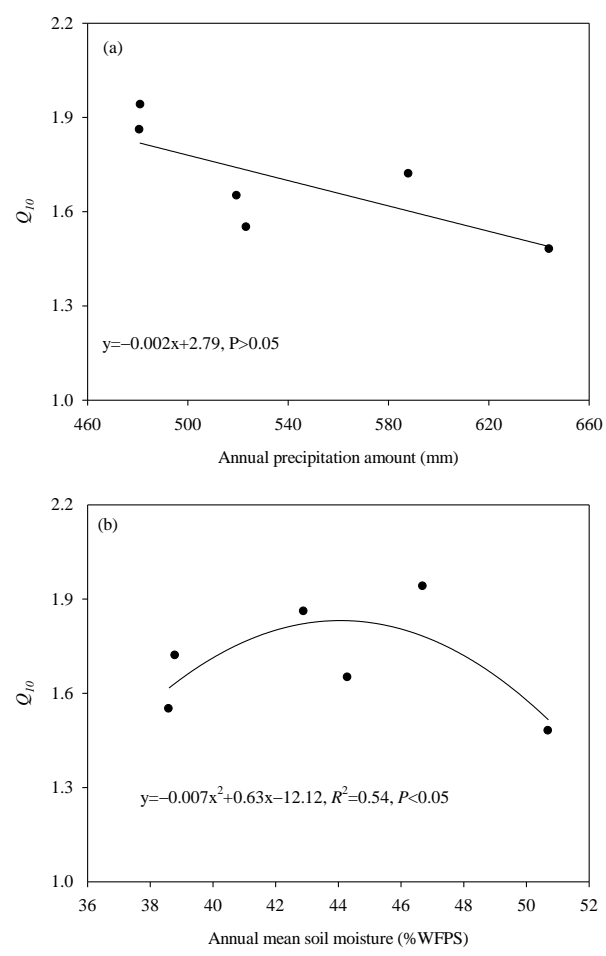

Figure 3. Regression analysis performed between (a) $Q_{10}$ and annual precipitation amount, and (b) $Q_{10}$ and annual mean soil moisture.

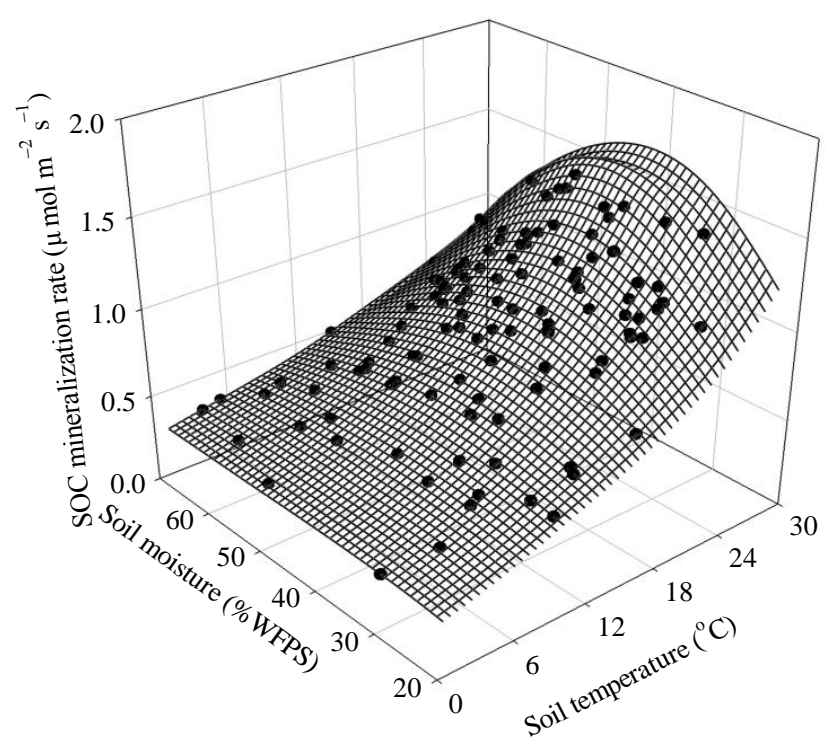

Figure 4. Response surface of SOC mineralization rate as a function of soil moisture and soil temperature from 2008 to 2013.

observation period of 2008-2013 ranged from 481 (2009) to $644 \mathrm{~mm}$ (2011), with a CV of $12 \%$ (Table 2). The annual mean soil moisture content was high (51\% WFPS) in 2011 due to the relatively uniform distribution of precipitation, and low (38\% WFPS) in 2010 and 2013 due to
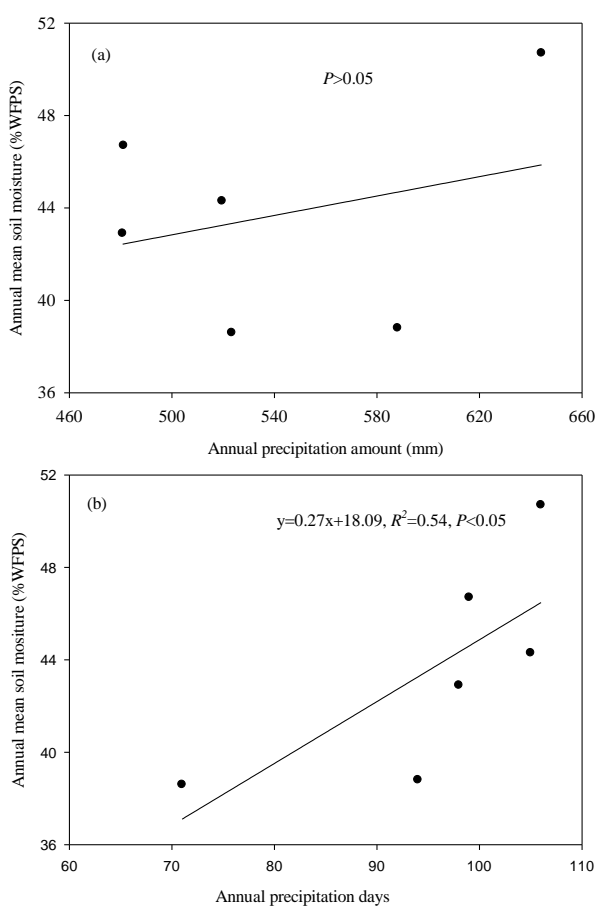

Figure 5. Regression analysis performed between (a) annual mean soil moisture and annual precipitation amount, and (b) annual mean soil moisture and annual precipitation days.

relatively uneven distribution of precipitation. For example, the rainfall amount on 23 July $2010(118 \mathrm{~mm})$ and 22 July $2013(121 \mathrm{~mm})$ was about 20 and $23 \%$ of that in 2010 $(588 \mathrm{~mm})$ and $2013(523 \mathrm{~mm})$, respectively. The annual mean soil moisture was moderate (43-47\% WFPS) in 2008, 2009, and 2012 due to the normal distribution of precipitation. Similarly, the interannual soil moisture regulation in the forest ecosystems in the Loess Plateau was determined not only by rainfall amount but also by rainfall distribution ( $\mathrm{Li}$ et al., 1998).

Annual $Q_{10}$ showed a negative quadratic relationship with soil moisture content, as it increased with increasing soil moisture content to a maximum at approximately $42 \%$ WFPS, and then decreased with further increase of soil moisture content (Fig. 3b), which was in agreement with other studies (Bowden et al., 1998; Conant et al., 2004; Smith, 2005). This could be for the following reasons: firstly, lower soil water availability could reduce $Q_{10}$ by limiting respiration substrate availability and soil pore water became increasingly disconnected, thus slowing down the diffusion rate of solutes (Wan et al., 2007; Balogh et al., 2011), and decreasing the activity and quantity of organisms due to drought stress (Davidson et al., 2006). Secondly, higher soil moisture could also reduce $Q_{10}$ by limiting $\mathrm{O}_{2}$ diffusion rate (Davidson et al., 1998; Byrne et al., 2005; Saiz et al., 2007) because of low effective soil porosity, as the diffusion rate of $\mathrm{O}_{2}$ through water was much slower than that through air (Cook and Knight, 


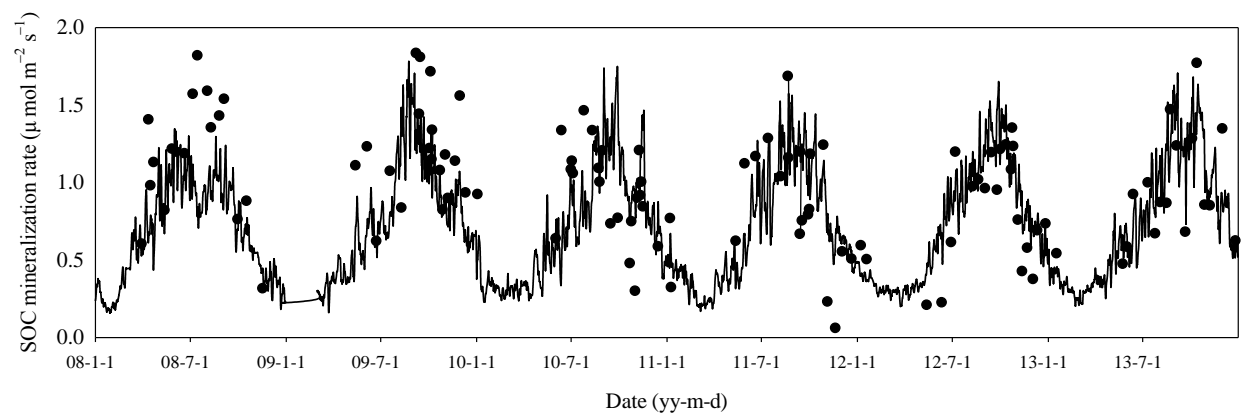

Figure 6. Estimated daily (2008-2013) SOC mineralization rate (solid line) with periodic measurement values (filled circles).

Table 4. Annual cumulative SOC mineralization rate $\left(\mathrm{g} \mathrm{C} \mathrm{m}^{-2} \mathrm{yr}^{-1}\right)$ estimated by linear interpolation method, modeled method, and unit conversed method from 2008 to 2013.

\begin{tabular}{lrrr}
\hline \multirow{2}{*}{ Years } & \multicolumn{3}{c}{ Annual cumulative SOC mineralization rate } \\
\cline { 2 - 4 } & Linear interpolation & Soil temperature and moisture modeled & Unit conversion \\
\hline 2008 & 293 & 258 & 462 \\
2009 & 298 & 272 & 460 \\
2010 & 238 & 268 & 344 \\
2011 & 234 & 260 & 325 \\
2012 & 226 & 271 & 314 \\
2013 & 240 & 284 & 348 \\
Mean & $255 \pm 32$ & $269 \pm 6$ & $374 \pm 65$ \\
\hline
\end{tabular}

Note: modeled method uses the interactions of soil temperature with moisture for estimating annual cumulative SOC mineralization rate with Eq. (4) (2.4 sections); unit conversion method estimates annual cumulative SOC mineralization rate with mean SOC mineralization rate in a given year.

2003; Manzoni et al., 2012), thus the decomposition activity of aerobic microbes was inhibited due to lack of oxygen (Davidson et al., 2000). Finally, the diffusion rate of both soluble organic matter and $\mathrm{O}_{2}$ was not inhibited, and the survival of microorganisms was not subject to water stress at suitable soil water content; instead increasing temperature increased the diffusion of soluble organic matter, thus resulting in an increase in $Q_{10}$ (McCulley et al., 2007). Overall, soil moisture content may be the most important factors that affected the interannual variation in $Q_{10}$.

The variation in the temperature sensitivities of SOC mineralization could have potential implications for climate carbon modeling (Davidson and Janssens, 2006; Conant et al., 2011), as uncertainty remains regarding environmental controls over SOC mineralization (Larionova et al., 2007; Karhu et al., 2010; Conant et al., 2011; Sakurai et al., 2012). The previous results have emphasized the importance of seasonal variation in precipitation and soil moisture in determining $Q_{10}$ (Xu and Qi, 2001; Davidson et al., 2006; Davidson and Janssens, 2006), but have rarely taken into account the interannual variation in soil moisture resulting from the uneven distribution of precipitation. Carbon cycle modeling without considering this interannual variation in soil moisture may produce misleading conclusions.

\subsection{Comparison with annual cumulative SOC mineralization rate estimated by different methods}

Annual cumulative SOC mineralization rate was estimated by different methods, including linear interpolation method, modeled method, and unit conversion method. The results clearly showed that there was no significant difference in the estimates of annual cumulative SOC mineralization rate between linear interpolation and modeled method, and the modeled method could well predict the SOC mineralization rate in most cases from 2008 to 2013 (Fig. 6), which was in line with the previous studies (Tang et al., 2005). However, the unit conversion method seriously overestimated the annual cumulative SOC mineralization rate (Table 4). This could be for the following reasons: (1) the study site has a continental monsoon climate with $60 \%$ of rainfall occurring from July to September (rainy season), thus the study site is hot and rainy in the rainy season, but cool and dry in the non-rainy season; and (2) SOC mineralization rate in the rainy and non-rainy season is largely the same, but the duration of rainy season is only a quarter of a year. Thus, the SOC mineralization rate was much greater in the rainy season than in the non-rainy season, thus resulting in an overestimation of cumulative SOC mineralization rate in a given year. 
In conclusion, the linear interpolation method is a simple and controllable method for estimating the annual cumulative SOC mineralization rate (Schindlbacher et al., 2014; Shi et al., 2014). Although the modeled method can well estimate annual cumulative SOC mineralization rate, it is limited in practice as it needs daily soil temperature and moisture. The unit conversion method may seriously overestimate annual cumulative SOC mineralization rate unless the SOC mineralization rate is very uniform in a given year.

\section{Conclusions}

Understanding the factors influencing the temperature sensitivity of SOC mineralization is important to accurately estimate local carbon cycle. The results of this study showed that the annual cumulative SOC mineralization ranged from 226 to $298 \mathrm{~g} \mathrm{C} \mathrm{m}^{-2} \mathrm{yr}^{-1}$, with a CV of $13 \%$, annual $Q_{10}$ ranged from 1.48 to 1.94 , with a $\mathrm{CV}$ of $10 \%$, and annual soil moisture content ranged from 38.6 to $50.7 \%$ WFPS, with a CV of $11 \%$. Annual $Q_{10}$ showed a negative quadratic correlation with annual mean soil moisture, which was determined by the uneven distribution and frequency of rainfall. In conclusion, the interannual variation in soil moisture content should be considered in carbon cycle models in semi-arid areas.

Author contributions. S. L. Guo and M. Zhao conceived and designed the experiments, R. Wang and N. N. Li performed the experiments, L. L. Du and J. S. Jiang analyzed the data, Y. J. Zhang and R. J. Li wrote the paper.

Acknowledgements. This study was funded by National Natural Science Foundation of China, no. 41371279. The anonymous reviewers were greatly appreciated for their constructive comments on the manuscript.

Edited by: N. Ohte

\section{References}

Ågren, G. I. and Wetterstedt, J.: What determines the temperature response of soil organic matter decomposition?, Soil Biol. Biochem., 39, 1794-1798, 2007.

Balogh, J., Pinter, K., Foti, S., Cserhalmi, D., Papp, M., and Nagy, Z.: Dependence of soil respiration on soil moisture, clay content, soil organic matter, and $\mathrm{CO}_{2}$ uptake in dry grasslands, Soil Biol. Biochem., 43, 1006-1013, 2011.

Boone, R. D., Nadelhoffer, K. J., Canary, J. D., and Kaye, J. P.: Roots exert a strong influence on the temperature sensitivity of soil respiration, Nature, 396, 570-572, 1998.

Bowden, R. D., Newkirk, K. M., and Rullo, G. M.: Carbon dioxide and methane fluxes by a forest soil under laboratory-controlled moisture and temperature conditions, Soil Biol. Biochem., 30, 1591-1597, 1998.
Byrne, K. A., Kiely, G., and Leahy, P.: $\mathrm{CO}_{2}$ fluxes in adjacent new and permanent temperate grasslands, Agr. Forest Meteorol., 135, 82-92, 2005.

Cable, J. M., Ogle, K., Lucas, R. W., Huxman, T. E., Loik, M. E., Smith, S. D., Tissue, D. T., Ewers, B. E., Pendall, E., and Welker, J. M.: The temperature responses of soil respiration in deserts: a seven desert synthesis, Biogeochemistry, 103, 71-90, 2011.

Cho, E. and Choi, M.: Regional scale spatio-temporal variability of soil moisture and its relationship with meteorological factors over the Korean peninsula, J. Hydrol., 516, 317-329, 2014.

Conant, R. T., Dalla-Betta, P., Klopatek, C. C., and Klopatek, J. M.: Controls on soil respiration in semiarid soils, Soil Biol. Biochem., 36, 945-951, 2004.

Conant, R. T., Ryan, M. G., Ågren, G. I., Birge, H. E., Davidson, E. A., Eliasson, P. E., Evans, S. E., Frey, S. D., Giardina, C. P., and Hopkins, F. M.: Temperature and soil organic matter decomposition rates-synthesis of current knowledge and a way forward, Glob. Change Biol., 17, 3392-3404, 2011.

Cook, F. and Knight, J.: Oxygen Transport to Plant Roots: modeling for physical understanding of soil aeration, Soil Sci. Soc. Am. J., 67, 20-31, 2003.

Coronato, F. R. and Bertiller, M. B.: Precipitation and landscape related effects on soil moisture in semi-arid rangelands of Patagonia, J. Arid Environ., 34, 1-9, 1996.

Davidson, E., Belk, E., and Boone, R. D.: Soil water content and temperature as independent or confounded factors controlling soil respiration in a temperate mixed hardwood forest, Glob. Change Biol., 4, 217-227, 1998.

Davidson, E. A. and Janssens, I. A.: Temperature sensitivity of soil carbon decomposition and feedbacks to climate change, Nature, 440, 165-173, 2006.

Davidson, E. A., Verchot, L. V., Cattanio, J. H., Ackerman, I. L., and Carvalho, J. E. M.: Effects of soil water content on soil respiration in forests and cattle pastures of eastern Amazonia, Biogeochemistry, 48, 53-69, 2000.

Davidson, E. A., Janssens, I. A., and Luo, Y. Q.: On the variability of respiration in terrestrial ecosystems: moving beyond $Q_{10}$, Glob. Change Biol., 12, 154-164, 2006.

Djukic, I., Zehetner, F., Mentler, A., and Gerzabek, M. H.: Microbial community composition and activity in different Alpine vegetation zones, Soil Biol. Biochem., 42, 155-161, 2010.

Dörr, H. and Münnich, K.: Annual variation in soil respiration in selected areas of the temperate zone, Tellus B, 39, 114-121, 1987.

Epron, D., Bosc, A., Bonal, D., and Freycon, V.: Spatial variation of soil respiration across a topographic gradient in a tropical rain forest in French Guiana, J. Trop. Ecol., 22, 565-574, 2006.

Fan, X. H. and Wang, M. B.: Change trends of air temperature and precipitation over Shanxi Province, China, Theor. Appl. Climatol., 103, 519-531, 2011.

Fang, C. and Moncrieff, J. B.: The dependence of soil $\mathrm{CO}_{2}$ efflux on temperature, Soil Biol. Biochem., 33, 155-165, 2001.

Gaumont-Guay, D., Black, T. A., Barr, A. G., Jassal, R. S., and Nesic, Z.; Biophysical controls on rhizospheric and heterotrophic components of soil respiration in a boreal black spruce stand, Tree Physiol., 28, 161-171, 2008.

Gershenson, A., Bader, N. E., and Cheng, W.: Effects of substrate availability on the temperature sensitivity of soil organic matter decomposition, Glob. Change Biol., 15, 176-183, 2009. 
Gulledge, J. and Schimel, J. P.: Controls on soil carbon dioxide and methane fluxes in a variety of taiga forest stands in interior Alaska, Ecosystems, 3, 269-282, 2000.

Guo, S., Zhu, H., Dang, T., Wu, J., Liu, W., Hao, M., Li, Y., and Syers, J. K.: Winter wheat grain yield associated with precipitation distribution under long-term nitrogen fertilization in the semiarid Loess Plateau in China, Geoderma, 189, 442-450, 2012.

Illeris, L., Christensen, T. R., and Mastepanov, M.: Moisture effects on temperature sensitivity of $\mathrm{CO}_{2}$ exchange in a subarctic heath ecosystem, Biogeochemistry, 70, 315-330, 2004.

Jassal, R. S., Black, T. A., Novak, M. D., Gaumont-Guay, D., and Nesic, Z.: Effect of soil water stress on soil respiration and its temperature sensitivity in an 18-year-old temperate Douglas-fir stand, Glob. Change Biol., 14, 1305-1318, 2008.

Jurasinski, G., Jordan, A., and Glatzel, S.: Mapping soil $\mathrm{CO}_{2}$ efflux in an old-growth forest using regression kriging with estimated fine root biomass as ancillary data, Forest Ecol. Manag., 263, 101-113, 2012.

Karhu, K., Fritze, H., Hämäläinen, K., Vanhala, P., Jungner, H., Oinonen, M., Sonninen, E., Tuomi, M., Spetz, P., and Kitunen, V.: Temperature sensitivity of soil carbon fractions in boreal forest soil, Ecology, 91, 370-376, 2010.

Kirschbaum, M. U. F.: The temperature dependence of organicmatter decomposition-still a topic of debate, Soil Biol. Biochem., 38, 2510-2518, 2006.

Lafond, J. A., Allaire, S. E., Dutilleul, P., Pelletier, B., Lange, S. F., and Cambouris, A. N.: Spatiotemporal Analysis of the Relative Soil Gas Diffusion Coefficient in Two Sandy Soils: Variability Decomposition and Correlations between Sampling Dates at Two Spatial Scales, Soil Sci. Soc. Am. J., 75, 1613-1625, 2011.

Larionova, A. A., Yevdokimov, I. V., and Bykhovets, S. S.: Temperature response of soil respiration is dependent on concentration of readily decomposable C, Biogeosciences, 4, 1073-1081, doi:10.5194/bg-4-1073-2007, 2007.

Li H. J., Wang M. B., and Chai B. F.: Study on characteristics of soil water of planted forest and its relation to precipitation in northwestern Shanxi, Journal of Soil Erosion and Soil and Water Conservation, 4, 60-65, 1998.

Lin, S. and Wang Y. R.: Spatial-temporal Evolution of Precipitation in China Loess Plateau, Journal of Desert Research, 27, 502-508, 2007.

Luan, J., Liu, S., Zhu, X., Wang, J., and Liu, K.; Roles of biotic and abiotic variables in determining spatial variation of soil respiration in secondary oak and planted pine forests, Soil Biol. Biochem., 44, 143-150, 2012.

Manzoni, S., Schimel, J. P., and Porporato, A.: Responses of soil microbial communities to water stress: results from a meta-analysis, Ecology, 93, 930-938, 2012.

McCulley, R. L., Boutton, T. W., and Archer, S. R.: Soil respiration in a subtropical savanna parkland: Response to water additions, Soil Sci. Soc. Am. J., 71, 820-828, 2007.

Peng, S. S., Piao, S. L., Wang, T., Sun, J. Y., and Shen, Z. H.: Temperature sensitivity of soil respiration in different ecosystems in China, Soil Biol. Biochem., 41, 1008-1014, 2009.

Poll, C., Marhan, S., Back, F., Niklaus, P. A., and Kandeler, E.: Field-scale manipulation of soil temperature and precipitation change soil $\mathrm{CO}_{2}$ flux in a temperate agricultural ecosystem, Agr. Ecosyst. Environ., 165, 88-97, 2013.
Qiu, Y., Fu, B. J., Wang, J., and Chen, L. D.: Spatial variability of soil moisture content and its relation to environmental indices in a semi-arid gully catchment of the Loess Plateau, China, J. Arid Environ., 49, 723-750, 2001.

Reth, S., Reichstein, M., and Falge, E.: The effect of soil water content, soil temperature, soil $\mathrm{pH}$-value and the root mass on soil $\mathrm{CO}_{2}$ efflux-A modified model, Plant Soil, 268, 21-33, 2005.

Reichstein, M., Tenhunen, J. D., Roupsard, O., Ourcival, J. M., Rambal, S., Dore, S., and Valentini, R.: Ecosystem respiration in two Mediterranean evergreen Holm Oak forests: drought effects and decomposition dynamics, Funct. Ecol., 16, 27-39, 2002.

Saiz, G., Black, K., Reidy, B., Lopez, S., and Farrell, E. P.: Assessment of soil $\mathrm{CO}_{2}$ efflux and its components using a processbased model in a young temperate forest site, Geoderma, 139, 79-89, 2007.

Sakurai, G., Jomura, M., Yonemura, S., Iizumi, T., Shirato, Y., and Yokozawa, M.: Inversely estimating temperature sensitivity of soil carbon decomposition by assimilating a turnover model and long-term field data, Soil Biol. Biochem., 46, 191-199, 2012.

Schindlbacher, A., Jandl, R., and Schindlbacher, S.: Natural variations in snow cover do not affect the annual soil $\mathrm{CO}_{2}$ efflux from a mid-elevation temperate forest, Glob. Change Biol., 20, 622632, 2014.

Shi, W. Y., Tateno, R., Zhang, J. G., Wang, Y. L., Yamanaka, N., and Du, S.: Response of soil respiration to precipitation during the dry season in two typical forest stands in the forest-grassland transition zone of the Loess Plateau, Agr. Forest Meteorol., 151, 854-863, 2011.

Shi, W. Y., Yan, M. J., Zhang, J. G., Guan, J. H., and Du, S.: Soil $\mathrm{CO}_{2}$ emissions from five different types of land use on the semiarid Loess Plateau of China, with emphasis on the contribution of winter soil respiration, Arid Environ., 88, 74-82, 2014.

Smith, V. R.: Moisture, carbon and inorganic nutrient controls of soil respiration at a sub-Antarctic island, Soil Biol. Biochem., 37, 81-91, 2005.

Solomon, S., Qin, D., Manning, M., Chen, Z., Marquis, M., Averyt, K., Tignor, M., and Miller, H.: Climate change 2007: the Physical Science Basis. Contribution of Working Group I to the Fourth Assessment Report of the Intergovernmental Panel on Climate Change, Cambridge Univ. Press, Cambridge, UK, 2007.

Suseela, V., Conant, R. T., Wallenstein, M. D., and Dukes, J. S.: Effects of soil moisture on the temperature sensitivity of heterotrophic respiration vary seasonally in an old-field climate change experiment, Glob. Change Biol., 18, 336-348, 2012.

Tang, J., Qi, Y., Xu, M., Misson, L., and Goldstein, A. H.: Forest thinning and soil respiration in a ponderosa pine plantation in the Sierra Nevada, Tree Physiol., 25, 57-66, 2005.

Von Lutzow, M. and Kogel-Knabner, I.: Temperature sensitivity of soil organic matter decomposition-what do we know?, Biol. Fert. Soils., 46, 1-15, 2009.

Wan, S., Norby, R. J., Ledford, J., and Weltzin, J. F.: Responses of soil respiration to elevated $\mathrm{CO}_{2}$, air warming, and changing soil water availability in a model old-field grassland, Glob. Change Biol., 13, 2411-2424, 2007.

Wang, B., Zha, T. S., Jia, X., Wu, B., Zhang, Y. Q., and Qin, S. G.: Soil moisture modifies the response of soil respiration to temperature in a desert shrub ecosystem, Biogeosciences, 11, 259-268, doi:10.5194/bg-11-259-2014, 2014. 
Wang, Q. X., Fan, X. H., Qin, Z. D., and Wang, M. B: Change trends of temperature and precipitation in the Loess Plateau Region of China, 1961-2010, Global Planet. Change, 92-93, 138147, 2012.

Xiao, L., Xue, S., Liu, G. B., and Zhang, C.: Soil Moisture Variability Under Different Land Uses in the Zhifanggou Catchment of the Loess Plateau, China, Arid Land Res. Manag., 28, 274-290, 2014.

$\mathrm{Xu}, \mathrm{M}$. and Qi, Y.: Spatial and seasonal variations of $Q_{10}$ determined by soil respiration measurements at a Sierra Nevadan forest, Global Biogeochem. Cy., 15, 687-696, 2001.
Zhou, X., Wan, S., and Luo, Y.: Source components and interannual variability of soil $\mathrm{CO}_{2}$ efflux under experimental warming and clipping in a grassland ecosystem, Glob. Change Biol., 13, 761775, 2007.

Zhu, B. and Cheng, W.: Rhizosphere priming effect increases the temperature sensitivity of soil organic matter decomposition, Glob. Change Biol., 17, 2172-2183, 2011.

Zimmermann, M., Leifeld, J., Conen, F., Bird, M. I., and Meir, P.: Can composition and physical protection of soil organic matter explain soil respiration temperature sensitivity?, Biogeochemistry, 107, 423-436, 2012. 